Of course, the application of foreign experience in the implementation of managerial innovations is necessary taking into account both national traditions and national interests.

Not only the experience of concrete directions of reforms of the systems of public administration in foreign countries, but also their socio-cultural and systemmanagement substantiation is of greatest importance for the domestic reform of the executive authorities. At the same time, the main problem of further research should be the problem of socio-cultural filling of the conceptual foundations of domestic administrative reform in the context of the processes of European integration.

Key words: administrative reform, public administration, public administration, system of executive authorities, territorial executive authorities, central executive authority.

УДК 351.741

Циганов О. Г.

доктор юридичних наук, доцент, головний науковий співробітник НДЛ проблем правового та організаційного забезпечення діяльності Міністерства ДНДІ МВС України (м. Київ, Україна)

\title{
ПІДХОДИ ДО З'ЯСУВАННЯ СУТНОСТІ ПОЛІЦЕЙСЬКИХ ПОСЛУГ: ВІТЧИЗНЯНІ РЕАЛІЇ ТА ЗАРУБІЖНА ПРАКТИКА
}

У статті досліджено «відсутність зброї» як ознака права на мирні зібрання. Досліджено загальноприйняте лінгвістичне розуміння поняття «зброя», а також нормативно закріплені поняття «зброя» у підзаконних нормативно-правових актах. На підставі аналізу поняття «зброя» та його співставлення з умовами здійснення права на мирні зібрання сформульовано складові елементи такої ознаки права на мирні зібрання, як «відсутність зброї».

Ключові слова: право на мирні зібрання, ознака, зброя, відсутність зброї.

Постановка проблеми. Надання послуг населенню за умов усебічної сервізації сфери публічного адміністрування перетворюється на магістральний напрям діяльності всіх органів державної влади, серед них і правоохоронних. У багатьох країнах світу поряд із традиційними завданнями поліції стратегічним напрямом розвитку цього органу правоохорони стає публічно-сервісний напрям.

Попри те, що на сьогодні в Україні нормативного визначення поняття «поліцейська послуга» не існує, можна стверджувати, що надання таких послуг є важливою складовою поліцейської діяльності. Утім, відсутність законодавчого визначення цього поняття, його властивостей та ознак стає основою для дискусій, відкриваючи необмежені можливості для дальших наукових досліджень. Водночас проведений нами аналіз засвідчив відмінності в розумінні категорії «поліцейська послуга» серед вітчизняних і зарубіжних фахівців у галузі публічного адміністрування.

Аналіз останніх досліджень і публікацій. Науковій розробці проблем поліцейської діяльності та ефективності ї̈ здійснення присвятили свої праці М. І. Ануфрієв, О.М.Бандурка, Ю.П.Битяк, В. М. Білик, В. О. Заросило, 
I. В. Зозуля, Ю. І. Римаренко, Д.П.Калаянов, О. Ф. Кобзар, А. Т. Комзюк, С. Ф. Константінов, О. О. Косиця, І. В. Кріцак, М. В. Лошицький, В. І. Олефір, О. С. Проневич, О. П. Угровецький, М. Ю. Фролов, О. С. Юнін, О. Н. Ярмиш та багато інших правників-науковців. Водночас питанням визначення сутності, змісту та ознак поліцейських послуг, їх нормативно-правового забезпечення та місця в структурі поліцейської діяльності належної уваги з боку вітчизняних науковців до цього часу приділено не було. Також звертають на себе увагу розбіжності в розумінні обсягів цього поняття в Україні та інших країнах.

Формування цілей. Метою статті $є$ розкриття особливостей встановлення сутності поліцейських послуг в Україні та зарубіжних країнах.

Виклад основного матеріалу. Якщо раніше термін «поліція» асоціювався 3 військовим, карально-репресивним способом функціонування, спрямованим на забезпечення законності й правопорядку в державі через виконання суто адміністративно-розпорядчих функцій, то за останні десятиліття в демократичних державах світу відбулися кардинальні зміни в концептуальному наповненні діяльності цього правоохоронного органу. На сьогодні поряд із традиційними завданнями поліції більш активним стає новий напрям їі діяльності, а саме - публічно-сервісний, який полягає в наданні послуг суспільству та окремим його членам у межах здійснення правоохоронної діяльності.

Відсутність законодавчого визначення поняття «поліцейська послуга», його властивостей та ознак стає основою для дискусій, відкриваючи необмежені можливості для дальших наукових досліджень. Вітчизняні науковці наділяють його різним змістом: одні стверджують, що вся діяльність поліції є сервісною [1, с. 24], інші вважають, що зазначене поняття в контексті поліцейської діяльності вказує на виконання обов'язків держави перед приватними особами, а прикметник «поліцейських» характеризує суб'єкта надання цих послуг [2, с. 19]. Такий погляд відображає інституціональний підхід до тлумачення досліджуваного поняття. Існує також думка, що надання в межах, визначених законом, послуг $з$ допомоги особам, які 3 особистих, економічних, соціальних причин або внаслідок надзвичайних ситуацій потребують такої допомоги, не може належати до завдань поліції, оскільки для цього існують інші державні органи [3]. Водночас аналіз наукових джерел і чинних нормативних актів засвідчив, що хоча поняття «послуги» трактується в них по-різному, проте сталим залишається розуміння цієї категорії як діяльності, що приносить користь, задовольняє певні людські потреби.

Відповідно до вітчизняної концепції публічних послуг визначено сутність, зміст та ознаки поліцейських послуг в Україні. На наш погляд, під категорією «поліцейська послуга» слід розуміти передбачену законом публічно-владну діяльність органу або підрозділу поліції, що грунтується й випливає з виконуваних цим органом (підрозділом) поліцейських функцій, безпосередньо пов'язаних із забезпеченням прав і свобод людини, інтересів суспільства і держави, протидією злочинності, підтриманням публічної безпеки і порядку, та виражається в здійсненні дій чи прийнятті рішень, 
котрі відбуваються в контакті 3 конкретною фізичною чи юридичною особою, яка переважно сама звертається до відповідного органу (підрозділу) поліції, його посадової особи для реалізації своїх суб'єктивних прав, свобод і законних інтересів або виконання покладених на неї нормативними правовими актами обов' язків у правоохоронній сфері [4, с. 103].

Проте невизначеність поняття «поліцейська послуга» в українському законодавстві та відсутність чіткого розуміння цієї категорії серед науковців створюють перешкоди в процесі правозастосування й унеможливлюють ефективне виконання працівниками поліції своїх обов'язків. Адже трудно зрозуміти, де межі функціонального обов'язку поліції, а де починається ії сервісна діяльність. У будь-якому випадку, до приведення наукових напрацювань та законодавчого тлумачення до усталеності, пересічні громадяни будуть ототожнювати ії 3 діяльністю ліквідованої «міліції», розуміючи їі як таку, що спрямована на захист їхніх прав та свобод, охорону й забезпечення громадського порядку, запобігання правопорушенням та їх припинення, участь у наданні соціальної та правової допомоги тощо.

Уведення нової термінологічної бази, невпорядкованість поліцейської діяльності й труднощі з упровадженням запропонованих законодавцем змін спонукають нас звертатися до міжнародного та зарубіжного досвіду у правоохоронній сфері, здійснюючи дальшу адаптацію запозиченого матеріалу відповідно до вітчизняних соціальних умов, правового поля та суспільного менталітету.

Передусім варто звернути увагу на міжнародні стандарти поліцейської діяльності. Неможна оминути подібність п. 4 ч. 1 ст. 2 Закону України «Про Національну поліцію» від 02 липня 2015 року № 580-VIII [5] 3 пунктом (с) Коментаря до ст. 1 Кодексу поведінки службовців органів правопорядку (затвердженого резолюцією Генеральної Асамблеї ООН від 17 грудня 1979 року № 34/169), де зазначається, що обслуговування суспільства охоплює надання послуг із допомоги представникові суспільства, який 3 особистих, економічних, соціальних чи інших надзвичайних ситуацій потребує негайної допомоги [6].

У додатку до Рекомендації Rec (2001) 10 Комітету Міністрів державамучасницям Ради Свропи «Про європейський кодекс поліцейської етики» (ухвалено Комітетом міністрів 19 вересня 2001 року на 756-му засіданні заступників міністрів) (далі - Рекомендації) визначено, що основними цілями поліції є: підтримка публічного спокою, забезпечення права й порядку в суспільстві; захист і дотримання основоположних прав і свобод особи; запобігання та подолання злочинності; виявлення злочинів; надання допомоги й послуг суспільству [7, с. 20].

Водночас у Пояснювальному меморандумі до Рекомендації зауважено, що в демократичних суспільствах, заснованих на верховенстві права, поліція надає різноманітні послуги соціального характеру, які супроводжують іншу iї діяльність [7, с. 24]. У цьому випадку забезпечення публічного порядку (або, іншими словами, спокою та закону в суспільстві), попередження злочинності, виявлення злочинів, дотримання основоположних прав i 
свобод осіб визначаються як традиційні функції поліції. Надання допомоги населенню окреслюється як ще один аспект поліцейської діяльності. До того ж залучення до завдань поліції функції з надання послуг є дещо іншим аспектом поліцейської діяльності, який суттєво змінює традиційну роль поліції в демократичному суспільстві. Поліція перестає бути «силою», яка застосовується до суспільства, і стає у цьому разі органом надання йому «послуг».

Протягом останніх років у Європейському Союзі простежується чітка тенденція повніше інтегрувати поліцію в громадянське суспільство й наблизити ї̈ до населення. Ця мета в низці держав-учасниць досягається за допомогою розвитку «діяльності поліції в інтересах громади» (community policing). Одним із головних засобів для досягнення цієї мети є наділення поліції статусом органу публічної служби, а не просто органу, відповідального за застосування закону.

У Пояснювальному меморандумі до Рекомендації вказується: «Зазвичай надання поліцією допомоги стосується конкретних ситуацій, у яких вона має бути зобов'язана втручатися, наприклад, коли потрібно надати допомогу людині в небезпеці або допомагати людям зв'язатися з іншими органами влади або соціальними службами, при цьому аспект «послуг» у діяльності поліції залишається розмитим, і він важко піддається визначенню. Його не можна плутати 3 деякими покладеними на поліцію адміністративними завданнями (наприклад, виданням паспортів). Загалом функція поліції як органу публічної служби пов'язана з роллю поліції як органу, до якого може звертатися населення, і доступність поліції є в цьому сенсі одним з найбільш важливих і основних елементів. Функція надання послуг поліцією більше пов'язана зі ставленням населення до поліції, ніж з наділенням ії широкими функціями з надання послуг на додаток до їі традиційних завдань» [7, с. 32].

Проте в згаданому Законі України «Про Національну поліцію» головне завдання поліції визначено вужче - воно полягає здебільшого в наданні поліцейських послуг у різних сферах, зокрема й щодо забезпечення публічної безпеки і порядку, охорони прав і свобод людини, інтересів суспільства і держави, протидії злочинності тощо [2, с. 379]. Отже, у згаданих документах визначено різний обсяг завдань, що належать до компетенції поліції.

Розглянемо положення законодавства окремих країн світу щодо надання поліцейських послуг.

У Законі Португальської Республіки про організацію поліції публічної безпеки № 53/2007 вказується на послуги спеціального характеру, які може надавати поліція публічної безпеки за окремими запитами [7, с. 205]. Такі послуги після затвердження рішення про їх надання компетентним органом оплачує заявник на визначених умовах. Поліція публічної безпеки може наділяти свій персонал поліцейськими функціями для надання послуг самоврядним структурам, центральній, регіональній та місцевій адміністрації, а також може взаємодіяти 3 іншими публічними або приватними структурами, які звертаються до неї для забезпечення безпеки осіб і майна або ж для надання інших послуг з чітко сформульованими 
запитами, рішення про виконання яких приймається індивідуально в кожному конкретному випадку. Оплата зазначених послуг урегульовується окремим законом або (за його відсутності) спільним наказом членів Уряду, відповідальних за внутрішню адміністрацію, фінанси та діяльність органу, який зажадав зазначені послуги.

Про спеціальні послуги йдеться також у Законі Сполученого Королівства про поліцію від 1996 року (англ. Police Act 1996, стосується Англії та Уельсу). Скажімо, у статті 25 закріплено право старшого офіцера сил поліції забезпечувати надання спеціальних поліцейських послуг на прохання будь-якої особи в будь-якому приміщенні або місці в межах поліцейського округу за умови, що ці послуги будуть оплачені за ставками, які може встановлювати цей орган. Зазначене стосується й Британських сил транспортної поліції [8].

Не можна оминути той факт, що трудність дослідження поліцейської практики англомовних країн пов' язана передусім зі складністю перекладу та різним змістом, який укладають у досліджуване поняття носії англійської та української мов. В англійській мові аналог слова «послуга» має не одне, а декілька значень - «service» може позначати як послугу, так і службу (орган, відомство), служіння, обслуговування, роботу тощо.

Окремої уваги заслуговує організація надання поліцейських послуг (англ. police services) у Сполучених Штатах Америки та Канаді. Особливість полягає в тому, що в цих країнах, по суті, немає єдиної системи поліції, звичної для нас, що пояснюється їх складним адміністративно-територіальним устроєм та багаторівневістю органів поліції. Як наслідок - організація та структура поліцейських органів може відрізнятися від штату до штату, від міста до міста.

Іншою особливістю організації надання поліцейських послуг у цих країнах є те, що поліцейське обслуговування на місцевому (не федеральному рівні) здійснюється на договірних засадах. Тобто округ (або декілька округів), місто чи невеликий населений пункт укладає з відповідним органом поліції договір про надання поліцейських послуг i, відповідно, оплачує за кошти місцевого бюджету ці послуги за умовами, передбаченими в документі. Отже, той обсяг функцій, який у наших правових реаліях поліцейський орган апріорі зобов'язаний виконувати, в американській і канадській системах виступає комплексом послуг, які поліція надає відповідній адміністративнотериторіальній одиниці на договірних засадах. Тобто поліцейський обов'язок збігається з поліцейською послугою; вони є невід'ємними один від одного.

Згідно із Законом «Про поліцейські послуги» Провінції Онтаріо (Канада) поліцейські послуги надаються на всій території Онтаріо відповідно до таких принципів: потреба в забезпеченні безпеки та охорони всіх людей та всього майна в Онтаріо; важливість забезпечення фундаментальних прав, гарантованих Канадською Хартією прав та свобод, а також Кодексом про права людини; потреба у співпраці між надавачами поліцейських послуг та громадами, які вони обслуговують; важливість поважного ставлення до потерпілих від злочинів та розуміння їхніх 
потреб; потреба в належному сприйнятті плюралістичного, багаторасового та багатокультурного характеру спільноти Онтаріо; потреба зробити поліцейські сили представниками тих громад, які вони обслуговують. Цей же нормативний акт передбачає мінімальний перелік основних послуг, надання яких зобов'язаний забезпечити поліцейський підрозділ муніципалітету. Серед них: попередження злочинів, забезпечення виконання законів, допомога потерпілим від злочинів, підтримка публічного порядку, ліквідація наслідків надзвичайних подій. Згідно 3 цим законодавчим актом муніципалітет несе відповідальність за забезпечення всієї інфраструктури та адміністрування, які є необхідними для належного надання зазначених послуг [9].

Відповідні особливості мають також поліцейські послуги, що надаються у США поліцейськими департаментами. Наприклад, у діяльності поліції частою $є$ така послуга, як перевірка будинку під час тривалої відсутності власників (англ. House Checks, House Security Checs, Vacation Inspection) [10]. Іншою незвичною для нас послугою поліції є реєстрація хворих на розлади свідомості, яким за зверненням близьких родичів одягають спеціальний браслет з даними поліцейського відділку (англ. At-risk dependent registration). Ще один різновид послуг - купуючи вживаний автомобіль, покупець може звернутися до поліції з проханням здійснити перевірку цього авто про знаходження у розшуку або перевірити, чи не значиться воно в страховій агенції як таке, що було затоплене (англ. VIN - Vehicle identification number) [11]. До інших актуальних послуг поліції належить: боротьба з графіті для збереження архітектури охоронюваної території [12]; консультування 3 питань особистої безпеки; реєстрація тварин; реєстрація дитячих велосипедів; патрулювання території на велосипедах.

Висновки. Проведений аналіз свідчить про неусталеність розуміння категорії «поліцейська послуга» серед вітчизняних і зарубіжних фахівців у галузі публічного адміністрування. 3 нашої погляду, відмінності обумовлені передусім різницею об'єктів матеріальної дійсності та їх утіленням в мові (тобто різницею обсягів понять), культурними, історичними та ментальними особливостями.

\section{Використані джерела:}

1. Проблеми теорії та практики інспекційної діяльності публічної адміністрації в Україні / автор-упорядник Банчук О. А. Київ: Конус Ю, 2009. 272 с.

2. Закон України «Про Національну поліцію» : наук.-практ. комент. МВС України, Харків. нац. ун-т внутр. справ / за заг. ред. Сокуренка В. В. Харків, 2016. 408 с.

3. Шалгунова С. А., Якушкін В. А. «Поліцейські послуги» чи виконання функцій держави по забезпеченню громадського порядку та безпеки. Порівняльноаналітичне право. 2016. № 1. С. 323 - 326.

4. Циганов О. Г. , Бабич І. С., Бойко І. В., Бурбій А. В. Поліцейська діяльність та поліцейські послуги в Украӥні: організаційно-правові аспекти : монографія. Вінниця: «Твори», 2019.196 с.

5. Про Національну поліцію : Закон України від 02 липня 2015 року № 580VIII. Відомості Верховної Ради України. 2015. № 40-41. 
6. Резолюція 34/169 Генеральної Асамблеї ООН «Кодекс поведінки посадових осіб з підтримання правопорядку» (OOH; Резолюція, Міжнародний документ, Кодекс від 17.12.1979). URL : http:/ / zakon5.rada.gov.ua/laws/show (дата звернення: 25.07.2017).

7. Статус поліції: міжнародні стандарти і зарубіжне законодавство / за заг. редакцією Банчука О. А. Київ: Москаленко О. М., 2013. 588 с.

8. Police Act 1996. URL: http://www.legislation.gov.uk/ukpga/1996 (дата звернення: 28.08.2017).

9. Police Services Act, R.S.O. 1990, P.15. URL : https://www.ontario.ca/laws/sta tute/90p15 (дата звернення: 26.07.2017).

10. The St. Louis County Police Department. URL : http://www. stlouisco.com /Lawand Public Safety/Police Department (дата звернення: 30.08.2017).

11. The Pevely Police Department. URL : http://www.cityofpevely.net/servicesprovided/ (дата звернення: 20.07.2017).

12. The Ferndale Police Department. URL : http:/ / www.ferndalepd.org/ serAntiGraffiti_Program (дата звернення: 01.09.2017).

Стаття надіӥшла до редколегії 07.02.2019

Цыганов О. Г., доктор юридических наук, доцент, главный научный сотрудник НИЛ проблем правового и организационного обеспечения деятельности Министерства ГНИИ МВД Украины (г. Киев, Украина)

Подходы к определению сущности полицейских услуг: отечественные реалии и зарубежная практика

Статья посвящена исследованию различий в понимании категории «полицейская услуга» как в Украине, так и за рубежом. Отсутствие определения понятия «полицейская услуга» в законодательстве Украины, его свойств и признаков становится основой для дискуссий среди отечественных ученых. В то же время различия в понимании этой категории в Украине, которое не в полной мере соответствует зарубежной практике, обусловлены, прежде всего, разницей объектов материальной действительности и их воплощением в языке (проще говоря - разницей объемов понятий), культурными, историческими и ментальными особенностями. Авторская дефиниция понятия «полицейская услуга» основывается на постулатах отечественной концепции публичных услуг.

Ключевые слова: правоохранительная деятельность, публично-сервисная деятельность, полицейская деятельность, полицейские услуги.

Tsyganov O. Approaches to Determination of the Nature of Police Services: Domestic Realities and Foreign Practice

The article is devoted to the study of differences in the understanding of the category "police service" in Ukraine and abroad. One of the initial conceptual foundations of the reform of the executive authorities of Ukraine is the need to reorient these bodies' activities for the implementation of purely administrative and regulatory functions to provide individuals and legal entities with quality and affordable public services. Despite the fact that there is no normative definition of police services in Ukraine today, it can be argued that the provision of such services is an important component of police activity. However, the lack of a legislative definition of the concept of "police service", its properties and features, becomes the basis for discussions, opening up unlimited opportunities for further research. 
In accordance with the national concept of public services, we have defined the essence, content and features of police services in Ukraine. From our point of view, the category "police service" should be understood as the law-governed public-authority activity of a body or police unit based and proceeding from the functions performed by that authority (unit) of police functions directly related to the protection of human rights and freedoms, interests society and state, counteraction to crime, maintenance of public security and order, and is expressed in the implementation of actions or decisions that take place in contact with a particular natural or legal person who is mainly refers to the relevant authority (unit) police, its officer to implement their subjective rights, freedoms and lawful interests or performance of its regulatory acts in law enforcement duties.

The introduction of a new terminology database, disorderly policing and complexity with the introduction of changes proposed by the legislator encourage us to turn to international and foreign law enforcement experience and implement further adaptation of borrowed material in accordance with domestic social conditions, legal framework and public mentality.

In order to implement positive experience, the article analyzes foreign and international normative sources regulating the issues of police services. Some aspects of providing police services in the United States and Canada are highlighted.

Key words: law enforcement, public service, police activities, police services.

УДК: 351.74(479.22+474)

Чумак В. В.

кандидат юридичних наук, провідний науковий співробітник відділу організації наукової роботи

Харківського національного університету внутрішніх справ (м. Харків, Україна)

\section{ІННОВАЦІЙНІ ПІДХОДИ ДО РОЗ'ЯСНЮВАЛЬНО- ПРЕВЕНТИВНОЇ ДІЯЛЬНОСТІ ПОЛІЦЇ ГРУЗІЇ ТА КРАЇН БАЛТІЇ: ДОСВІД ДЛЯ УКРАЇНИ}

У статті проаналізовано інноваційні форми та методи роз'яснювальнопревентивної діяльності поліції Грузії та країн Балтії. Охарактеризовано символи латвійської, литовської та естонської поліції, запроваджені як засіб превентивної діяльності поліції вказаних країн. Виснувано, що для якісного реформування поліції в Україні потрібно вивчати зарубіжний позитивний досвід та впроваджувати його для забезпечення успішної реалізації роз'яснювальнопревентивної діяльності поліції.

Ключові слова: інновації, превенція, профілактика, роз'яснювальнопревентивна діяльність, символи поліції, реформа, Грузія, країни Балтії, Україна.

Постановка проблеми. Розпад Союзу Радянських Соціалістичних Республік (далі - СРСР) ознаменував для кожної з ії країн, що вийшли зі складу, початок становлення незалежної, правової та демократичної держави, початок державного будівництва та формування громадянського суспільства. Грузія та країни Балтії, як колишні країни-члени СРСР, активно почали впроваджувати власні стандарти функціонування державних

(C) Чумак В. В., 2019 